\title{
Pemenuhan Kewajiban Adat sebagai Pidana Tambahan dalam RUU KUHP
}

\author{
Lidya Suryani Widayati \\ P3DI Setjen DPR RI Lt. II Ruang Staf Ahli Gedung Nusantara I DPR RI Jakarta \\ Jl. Jenderal Gatot Subroto Jakarta 10270. Gedung Nusantara III Jakarta \\ lidyadhi@yahoo.com, lidya.widayati@dpr.go.id
}

\begin{abstract}
"The fulfillment of local traditional obligation or obligation prevailing in the local community" as an additional crime in the Draft Plan of Criminal Code means that the law allows the regulation existing in the community (indigenous criminal law) which does not have an equivalent in the prevailing regulations of law to be a legal source". In this matter, the law enforcers must be able to assess whether there is really a traditional crime reported by the victim. The difference between the criminal code and the indigenous criminal law principles must also be known and anticipated by the law enforcers. This research studies the additional criminal sanction from the perspective of restorative justice that is the indigenous law concept which requires the willingness and participation of the victim, perpetrator, and the community in order to find solution for the crime conducted. This research which uses the secondary data by literature study and the primary data using interview concludes that "the fulfillment of the local traditional obligation or obligation prevailing in the local community" meets the restorative justice principles. However, a comprehensive study is needed to include the restorative justice system into Draft Plan of Criminal Code and Draft Plan of Civil Code to create the synchronization and harmony between material criminal law and normative criminal law.
\end{abstract}

Key words: Additional crime, fulfillment of indigenous obligation, restorative justice

\begin{abstract}
Abstrak
"Pemenuhan kewajiban adat setempat atau kewajiban menurut hukum yang hidup dalam masyarakat", sebagai pidana tambahan dalam RUU KUHP berarti bahwa undang-undang membolehkan hukum yang hidup dalam masyarakat (hukum pidana adat) yang tidak ada padanannya dalam peraturan perundang-undangan menjadi sumber hukum". Dalam hal ini, aparat penegak hukum harus dapat "menguji" apakah memang terdapat tindak pidana adat yang dilaporkan oleh korban. Perbedaan prinsip yang dianut hukum pidana dengan hukum pidana adat juga harus diketahui dan dapat diantisipasi oleh aparat penegak hukum. Penelitian ini mengkaji sanksi pidana tambahan dari perspektif restorative justice (keadilan restoratif) yang merupakan konsep hukum adat yang mensyaratkan kerelaan dan partisipasi dari korban, pelaku dan masyarakat dalam melakukan perbaikan atas tindak pidana yang terjadi. Penelitian dengan menggunakan data sekunder melalui studi kepustakaan dan data primer melalui wawancara ini, menyimpulkan bahwa "pemenuhan kewajiban adat setempat atau kewajiban menurut hukum yang hidup dalam masyarakat" memenuhi prinsip restorative justice. Namun demikian, perlu dilakukan kajian komprehensif untuk memasukkan restorative justice system ke dalam RUU KUHP dan RUU KUHAP agar terdapat sinkronisasi dan harmonisasi antara hukum pidana materiil dan hukum pidana formil.
\end{abstract}

Kata kunci: Pidana tambahan, pemenuhan kewajiban adat, restorative justice. 


\section{Pendahuluan}

Jika dibandingkan dengan Kitab Undang-Undang Hukum Pidana (KUHP), ketentuan mengenai pemidanaan dalam Rancangan Undang-Undang tentang KitabUndang-Undang Hukum Pidana (RUU KUHP) ${ }^{1}$ mengalami beberapa perubahan mendasar. Dalam bab mengenai pemidanaan, pidana, dan tindakan di antaranya berisi tentang tujuan pemidanaan, pedoman pemidanaan, perubahan atau penyesuaian pidana, pedoman penerapan pidana penjara dengan perumusan tunggal dan perumusan alternatif, jenis pidana, dan faktor-faktor yang memperingan dan memperberat pidana. RUU KUHP menganut sistem pemidanaan dua jalur (double track system), yaitu pelaku tindak pidana selain dapat dijatuhi sanksi pidana (criminal punishment), dapat juga dikenakan berbagai tindakan (treatment). Selain itu, jenis-jenis pidana dalam RUU KUHPjuga bertambah dengan diadopsinya pidana pokok baru yaitu pidana kerja sosial dan pidana pengawasan. RUU KUHP juga mengadopsi pidana tambahan baru yaitu pidana pembayaran ganti kerugian dan pidana pemenuhan kewajiban adat setempat dan/atau kewajiban menurut hukum yang hidup dalam masyarakat.

Sanksi pidana tambahan berupa "pemenuhan kewajiban adat setempat dan/atau kewajiban menurut hukum yang hidup dalam masyarakat", terkait dengan pelunakan/ penghalusan atau pergeseran/perluasan asas legalitas ${ }^{2}$ dalam hukum positif dan perkembangannya di Indonesia, yaitu UUDS Tahun 1950; UU No. 1 Drt. Tahun 1951; UU No. 14 Tahun 1970 jo UU No. 35 Tahun 19993; dan RUU KUHP. Dalam hal ini, asas legalitas tidak semata-mata diartikan sebagai "nullum delictum sine lege", tetapi juga sebagai "nullum delictum sine ius" atau tidak semata-mata dilihat sebagai asas legalitas formil, tetapi juga asas legalitas materiil, yaitu dengan mengakui hukum pidana adat,

\footnotetext{
${ }^{1}$ Buku I, Rancangan Undang-Undang Kitab Undang-Undang Hukum Pidana (RUU KUHP), Kementerian Hukum dan Hak Asasi Manusia, Draf Tahun 2012.

${ }^{2}$ Asas legalitas menghendaki adanya ketentuan yang pasti terlebih dahulu, baik mengenai perbuatan terlarang yang dapat dipidana maupun mengenai sanksi pidana itu sendiri. Asas legalitas (principle of legality) menentukan bahwa tidak ada perbuatan yang dilarang dan diancam dengan pidana jika tidak ditentukan terlebih dahulu dalam perundangundangan. Asas ini dikenal dalam bahasa latin sebagai nullum delictum nulla poena sine praevia lege (tidak ada tindak pidana tidak ada pidana tanpa peraturan lebih dahulu). Asas legalitas mengandung tiga makna atau pengertian, yaitu sebagai berikut. Pertama, tidak ada perbuatan yang dilarang dan diancam dengan pidana kalau hal itu terlebih dahulu belum dinyatakan dalam suatu aturan undang-undang. Kedua, untuk menentukan adanya perbuatan pidana tidak boleh digunakan analogi (kias). Ketiga, aturan-aturan hukum pidana tidak berlaku surut. Moeljatno, Asas-Asas Hukum Pidana, Rineka Cipta, Jakarta, 2008, hlm. 26.

${ }^{3}$ UU No. 14 Tahun 1970 tentang Ketentuan-Ketentuan Pokok Kekuasaan Kehakiman jo UU No. 35 Tahun 1999 tentang Perubahan UU No. 14 Tahun 1970 tentang Ketentuan-Ketentuan Pokok Kekuasaan Kehakiman sudah diganti dengan UU No. 4 Tahun 2004 tentang Kekuasaan Kehakiman. Selanjutnya UU No. 4 Tahun 2004 dicabut dan diganti dengan UU No. 48 Tahun 2009 tentang Kekuasaan Kehakiman.
} 
hukum yang hidup atau hukum tidak tertulis sebagai sumber hukum. ${ }^{4}$ Dalam RUU KUHP, diakuinya tindak pidana adat dengan tetap memasukkan unsur kesalahan ${ }^{5}$ adalah dengan dicantumkannya "pemenuhan kewajiban adat setempat dan/atau kewajiban menurut hukum yang hidup dalam masyarakat" sebagai sanksi pidana tambahan. RUU KUHP juga menentukan bahwa " pemenuhan kewajiban adat setempat atau kewajiban menurut hukum yang hidup dalam masyarakat" merupakan pidana pokok atau yang diutamakan, jika tindak pidana yang dilakukan memenuhi ketentuan sebagai-mana dimaksud dalam Pasal 2 ayat (1). ${ }^{6}$ Penjatuhan pidana tambahan ini dapat dijatuhkan bersama-sama dengan pidana pokok, sebagai pidana yang berdiri sendiri atau dapat dijatuhkan bersama-sama dengan pidana tambahan yang lain.

Pasal 100 ayat (1) RUU KUHP menentukan bahwa dengan memperhatikan ketentuan sebagaimana dimaksud dalam Pasal 2 ayat $(2)^{7}$ hakim dapat menetapkan pidana "pemenuhan kewajiban adat setempat dan/atau kewajiban menurut hukum yang hidup dalam masyarakat" yang harus dilakukan terpidana, jika keadaan menghendaki untuk memulihkan keseimbangan dan mendatangkan rasa damai dalam masyarakat. Tujuan pemidanaan bukan semata-mata menghukum pelaku, tetapi juga mendatangkan rasa damai dan memulihkan keseimbangan dalam masyarakat.

Dalam pandangan adat, tidak ada ketentuan yang keberlakuannya disertai dengan syarat yang menjamin ketaatannya dengan jalan menggunakan paksaan. Sanksi adat tidak sama pengertiannya dengan pemidanaan sebagaimana yang dijabarkan dalam teori-teori pemidanaan klasik karena tujuannya berbeda. Suatu penerapan sanksi adat adalah suatu upaya, untuk mengembalikan langkah yang berada di luar garis kosmos demi tidak terganggunya ketertiban kosmos. Jadi sanksi adat merupakan usaha mengembalikan keseimbangan yang terganggu. ${ }^{8}$

Sanksi pidana tambahan "pemenuhan kewajiban adat setempat dan/atau kewajiban menurut hukum yang hidup dalam masyarakat" juga bertujuan untuk

\footnotetext{
${ }^{4}$ Barda Nawawi Arief, Kapita Selekta Hukum Pidana, Citra Aditya Bakti, Bandung, 2010, hlm. 11.

${ }^{5}$ Asas kesalahan menghendaki agar hanya orang yang benar-benar bersalah sajalah yang dapat dikenakan pidana. Asas kesalahan digunakan sebagai persyaratan dalam memidana pelaku. Dikutip dari Muladi dan Barda Nawawi, TeoriTeori dan Kebijakan Pidana, Alumni, Bandung, 1998, hlm. 127.

${ }^{6}$ Pasal 2 ayat (1) menentukan bahwa ketentuan sebagaimana dimaksud dalam Pasal 1 ayat (1) tidak mengurangi berlakunya hukum yang hidup dalam masyarakat yang menentukan bahwa seseorang patut dipidana walaupun perbuatan tersebut tidak diatur dalam peraturan perundang undangan.

${ }^{7}$ Ketentuan Pasal 2 ayat (2) menyebutkan bahwa berlakunya hukum yang hidup dalam masyarakat adalah sepanjang sesuai dengan nilai-nilai yang terkandung dalam Pancasila, hak asasi manusia, dan prinsip-prinsip hukum umum yang diakui oleh masyarakat bangsa-bangsa.

${ }^{8}$ I Gede A.B. Wiranata, Hukum Adat Indonesia Perkembangan dari Masa ke Masa, dalam Eva Achjani Zulfa, Pergeseran Paradigma Pemidanaan, Lubuk Agung, Bandung, 2001, hlm. 70.
} 
memberikan perlindungan terhadap korban. ${ }^{9}$ Ide untuk memberikan perlindungan kepada korban kejahatan juga menjadi perhatian dalam Kongres PBB ke-10 tahun 2000 (dokumen A/CONF. 187/4/Rev.3), antara lain melalui mekanisme mediasi dan peradilan restorative (restorative justice). Kemudian, sebagai tindak lanjut pertemuan internasional tersebut mendorong munculnya dokumen internasional yang berkorelasi dengan peradilan restoratif dan mediasi dalam perkara pidana berupa the Recommendation of the Council of Eure 1999 No. R (99) 19 tentang "Mediation in Penal Mattres", berikutnya the EU Framework Decision 2001 tentang " the Standing of Victim in Criminal Proceedings" dan The UN Principles 2002 (Resolusi Ecosoc 2002/12) tentang "Basic Principles on the Use Restorative Justice Programmes in Criminal Matters". ${ }^{10}$

Keinginan dan usaha untuk melakukan kajian/penggalian hukum yang hidup juga menunjukkan kecenderungan adanya ketidakpuasan, keprihatinan, dan krisis kepercayaan terhadap sistem hukum dan kebijakan hukum yang ada selama ini.Kecenderungan demikian juga menjadi kecenderungan kongres-kongres internasional di bidang hukum pidana dan kriminologi. ${ }^{11}$ Demikian pula dalam dokumen internasional dan KUHP negara-negara lain juga terlihat perkembangan/ pengakuan ke arah asas legalitas materiil. Pasal 15 ayat (2) International Convention on Civil and Political Rights (ICCPR) menentukan bahwa, "Nothing in this article shall prejudice the trial and punishment of any person for any act or omission which, at the time when it was committed, was criminal according to the general principles of law recognized by the community of nations". ${ }^{2}$

Namun, menurut Barda Nawawi Arief, menggali hukum yang hidup tidak berarti mengangkat begitu saja hukum pidana adat dan hukum agama menjadi hukum pidana positif nasional. Hal yang patut digali adalah berbagai kesamaan asas-asas dan norma-norma hukum pidana yang terkandung di dalam hukum yang hidup. Dari berbagai kesamaan asas dan norma itulah, setelah dikaji dan diuji oleh nilai-nilai nasional yaitu nilai-nilai Pancasila, dapat kiranya diangkat menjadi asasasas dan norma-norma hukum pidana positif nasional. ${ }^{13}$

\footnotetext{
${ }^{9}$ Barda Nawawi Arief, Kapita Selekta Hukum, Op. Cit., hlm. 57.

${ }^{10}$ Barda Nawawi Arief, Mediasi Penal: Penyelesaian Perkara Pidana di Luar Pengadilan, http:// bardanawawi.wordpress.com/2009/12/27/mediasi penal penyelesaian perkara pidana di luar pengadilan/, diakses tanggal 20 Agustus 2012.

${ }^{11}$ Barda Nawawi Arief, Kapita Selekta..., Op. Cit., hlm. 49.

${ }^{12}$ Ibid., hlm. 12.

${ }^{13}$ Barda Nawawi Arief, Beberapa Aspek Kebijakan Penegakan dan Pengembangan Hukum Pidana, Citra Aditya Bakti, Bandung, 1998, hlm. 125.
} 
Terkait dengan beberapa ketentuan RUU KUHP mengenai legalitas materiil dan sanksi pidana tambahan berupa "pemenuhan kewajiban adat setempat dan/ atau kewajiban menurut hukum yang hidup dalam masyarakat", maka dengan demikian jika terjadi pelanggaran terhadap hukum yang hidup dalam masyarakat akan ditegakkan melalui proses formal. Pelakunya akan diproses melalui proses penyelidikan, penyidikan, dan proses pemeriksaan di pengadilan. Permasalahan yang mungkin timbul adalah bagaimana penerapannya, bagaimana seorang polisi membuat berita acara, dan bagaimana seorang jaksa akan menyusun surat dakwaannya karena hukum yang hidup dalam masyarakat tidak dapat diperkirakan, senantiasa tumbuh, berkembang, dan berubah termasuk tentang dilarang atau tidaknya suatu perbuatan. Dalam praktek, terhadap tindak pidana yang memiliki dasar hukum tertulis pun sering terjadi pengembalian berkas perkara oleh jaksa kepada pihak kepolisian karena dianggap belum lengkap.

Demikian pula mengenai pertanggungjawaban pelaku, jika hukum pidana menganut pertanggungjawaban individu, dalam hukum adat pertanggungjawaban pidana tidak selalu pertanggungjawaban individu. Sanksi pidana adat dapat pula dijatuhkan pada orang lain yang bukan pelaku, melainkan juga kepada keluarga pelaku. Sedangkan beberapa daerah di Indonesia seperti tanah Gayo, Tapanuli, Nias, Minangkabau, Sumatera Selatan, Kalimantan, Gorontalo, Ambon, Bali, dan Lombok seringkali terjadi bahwa kampung si pelaku atau kampung tempat terjadinya suatu pembunuhan atau pencurian terhadap orang asing (bukan orang kampung yang bersangkutan) diwajibkan membayar denda atau kerugian kepada kerabat orang yang dibunuh atau yang kecurian tersebut. Begitu pula kerabat si pelaku diharuskan menanggung hukuman yang dijatuhkan atas kejahatan yang dilakukan oleh seorang warganya. ${ }^{14}$

\section{Rumusan Masalah}

Berdasarkan latar belakang masalah tersebut, maka permasalahan penelitian ini adalah: pertama, bagaimana peluang penerapan sanksi pidana berupa "pemenuhan kewajiban adat setempat atau kewajiban menurut hukum yang hidup dalam masyarakat? Kedua, apakah pidana "pemenuhan kewajiban adat setempat atau kewajiban menurut hukum yang hidup dalam masyarakat” sejalan dengan prinsip restorative justice system?

${ }^{14}$ Tolib Setiady, Intisari Hukum Adat Indonesia (dalam Kajian Kepustakaan), Alfabeta, Bandung, 2008, hlm. 372. 


\section{Tujuan Penelitian}

Penelitian ini bertujuan untuk: pertama, mengetahui peluang penerapan sanksi pidana berupa "pemenuhan kewajiban adat setempat atau kewajiban menurut hukum yang hidup dalam masyarakat". Kedua, untuk mengetahui pidana "pemenuhan kewajiban adat setempat atau kewajiban menurut hukum yang hidup dalam masyarakat" apakah sejalan dengan prinsip restorative justice system.

\section{Metode Penelitian}

Penelitian ini merupakan penelitian hukum empiris. Jenis data yang digunakan dalam penelitian ini, adalah data sekunder (secondary data) melalui penelitian kepustakaan dan data primer (primary data) melalui penelitian lapangan melalui wawancara dengan para pihak yang berkompeten dan relevan dengan objek yang diteliti.

Penelitian lapangan dilaksanakan di Jayapura-Papua, Muara Enim dan Palembang-Sumatera Selatan, masing-masing tanggal 30 September-6 Oktober 2012 untuk Jayapura-Papua dan 28 Oktober-3 November 2012 untuk Muara Enim dan Palembang-Sumatera Selatan.

Kerangka analisis yang digunakan dalam penelitian ini adalah analisis kualitatif. Analisis kualitatif lebih menekankan analisis terhadap kualitas data daripada kuantitas data itu sendiri untuk mengungkapkan karakternya yang khas, pengertiannya, konteks sosialnya, dan relasinya satu sama lain melalui deskripsi dan interpretasi.

\section{Hasil Penelitian dan Pembahasan}

\section{Peluang Penerapan Sanksi Pidana Berupa "Pemenuhan Kewajiban Adat Setempat} Atau Kewajiban Menurut Hukum yang Hidup dalam Masyarakat".

Dalam RUU KUHP, asas legalitas ${ }^{15}$ yang tetap merupakan salah satu sendi hukum pidana Indonesia, ditafsirkan meliputi pula hukum pidana adat (tindak

${ }^{15}$ Asas legalitas menghendaki adanya ketentuan yang pasti terlebih dahulu, baik mengenai perbuatan terlarang yang dapat dipidana maupun mengenai sanksi pidana itu sendiri. Asas legalitas (principle of legality) menentukan bahwa tidak ada perbuatan yang dilarang dan diancam dengan pidana jika tidak ditentukan terlebih dahulu dalam perundangundangan. Asas ini dikenal dalam bahasa latin sebagai nullum delictum nulla poena sine praevia lege (tidak ada tindak pidana tidak ada pidana tanpa peraturan lebih dahulu). Asas legalitas mengandung tiga makna atau pengertian, yaitu sebagai berikut. Pertama, tidak ada perbuatan yang dilarang dan diancam dengan pidana kalau hal itu terlebih dahulu 
pidana adat). ${ }^{16}$ Dalam RUU KUHP, diakuinya tindak pidana adat (dengan tetap memasukan unsur kesalahan ${ }^{17}$ sebagai persyaratan dalam memidana pelaku), yaitu dengan dicantumkannya "pemenuhan kewajiban adat setempat atau kewajiban menurut hukum yang hidup dalam masyarakat" sebagai pidana tambahan. Dalam hal ini, hakim dapat menetapkan kewajiban menurut hukum yang hidup dalam masyarakat yang harus dilakukan terpidana, jika keadaan menghendaki untuk memulihkan keseimbangan dan mendatangkan rasa damai dalam masyarakat.Tujuan pemidanaan bukan semata-mata menghukum pelaku, tetapi juga mendatangkan rasa damai dan memulihkan keseimbangan dalam masyarakat.

"Pemenuhan kewajiban adat setempat atau kewajiban menurut hukum yang hidup dalam masyarakat," terkait pula dengan adanya perluasan asas legalitas dalam RUU KUHP. Pasal 1 ayat (3) RUU KUHP menentukan konsep yang berbeda dari adagium nullum delictum nulla poena sine praevia lege. Ayat (3) menentukan bahwa ketentuan sebagaimana dimaksud pada ayat (1) tidak mengurangi berlakunya hukum yang hidup dalam masyarakat yang menentukan bahwa seseorang patut dipidana walaupun perbuatan tersebut tidak diatur dalam peraturan perundang undangan.Selanjutnya ayat (4) menentukan bahwa berlakunya hukum yang hidup dalam masyarakat sebagaimana dimaksud pada ayat (3) sepanjang sesuai dengan nilai-nilai Pancasila dan/atau prinsip-prinsip hukum umum yang diakui oleh masyarakat bangsa-bangsa.

Adanya ketentuan Pasal 1 ayat (3) dan ayat (4) RUU KUHP tersebut maka seseorang dapat dituntut dan dipidana atas dasar hukum yang hidup dalam masyarakat meskipun perbuatan tersebut tidak dilarang dalam perundangundangan. Penjelasan Pasal 1 ayat (3) RUU KUHP menyebutkan: suatu kenyataan bahwa dalam beberapa daerah tertentu di Indonesia masih terdapat ketentuan hukum yang tidak tertulis yang hidup dalam masyarakat dan berlaku sebagai hukum di daerah tersebut. Hal yang demikian terdapat juga dalam lapangan hukum pidana yaitu yang biasanya disebut dengan tindak pidana adat.Untuk memberikan dasar hukum yang mantap mengenai berlakunya hukum pidana adat, maka hal tersebut mendapat pengaturan secara tegas dalam Kitab Undang-

belum dinyatakan dalam suatu aturan undang-undang. Kedua, untuk menentukan adanya perbuatan pidana tidak boleh digunakan analogi (kias). Ketiga, aturan-aturan hukum pidana tidak berlaku surut. Dikutip dari Moeljatno, AsasAsas Hukum Pidana, Rineka Cipta, Jakarta, 2008, hlm. 26.

${ }^{16}$ Mardjono Reksodiputro, Menyelaraskan Pembaruan Hukum, Jakarta, Komisi Hukum Nasional (KHN), 2009, hlm. 35 .

${ }^{17}$ Asas kesalahan menghendaki agar hanya orang yang benar-benar bersalah sajalah yang dapat dikenakan pidana. Dikutip dari Muladi dan Barda Nawawi, Teori-Teori dan Kebijakan Pidana, Alumni, Bandung, 1998, hlm. 127. 
undang Hukum Pidana ini. Ketentuan pada ayat ini merupakan pengecualian dari asas bahwa ketentuan pidana diatur dalam peraturan perundang-undangan. Diakuinya tindak pidana adat tersebut untuk lebih memenuhi rasa keadilan yang hidup di dalam masyarakat tertentu.

Menurut Basir Rohrohmana, ${ }^{18}$ hukum yang hidup dalam masyarakat (the Living Law) adalah hukum yang sebagian terbesar tidak tertulis yang ada dan berlaku dalam persekutuan masyarakat tertentu, hukum tersebut ditaati dan dijadikan patokan berperilaku dalam menjalin hubungan sesama warga masyarakat (anggota masyarakat dari persekutuan hukum). Di samping itu hukum yang hidup dalam masyarakat senantiasa menjaga tiga relasi utama yaitu relasi sesama manusia (warga/anggota masyarakat), relasi manusia dengan alamnya, dan relasi manusia dengan Tuhan Maha Pencipta.

Sedangkan menurut Muhammad Ikhsan, ${ }^{19}$ hukum yang hidup dalam masyarakat atau living law adalah fenomena sosial yang berkembang yang terformulasi dalam kaidah hukum dan rasa keadilan masyarakat yang tumbuh dan berkembang dalam masyarakat dan keberadaannya diterima di masyarakat, kebiasaan yang timbul diikuti serta ditaati, secara terus menerus dan turun temurun oleh masyarakat serta secara berkesinambungan hadir dalam kehidupan masyarakat tersebut.

Namun menurut Basir Rohrohmana, ${ }^{20}$ sulit untuk menetapkan dengan pasti perbuatan apa saja yang dikualifisir sebagai tindak pidana adat atau sebagai hukum yang hidup dalam masyarakat. Setiap pelanggaran tata hukum yang dianggap mengganggu keseimbangan kosmis adalah pelanggaran adat (tindak pidana adat). Setiap tindak pidana adat menimbulkan sanksi adat yang bertujuan untuk memulihkan keseimbangan tata hukum dan keseimbangan kosmis termasuk hukuman badan, harta benda, dan sanksi pidana non-fisik terberat yakni dikeluarkan dari lingkungan tata hukum persekutuan masyarakat bersangkutan.

Di Sumatera Selatan, tindak pidana adat pernah diberlakukan yang mengacu pada Simbur Cahaya atau Piagam Ratu Sinuhun, yaitu kitab aturan adat pada masyarakat Sumatera Selatan. Kitab Simbur Cahaya adalah kitab undang-undang adat yang pernah berlaku pada masyarakat Sumatera Selatan yang dianggap sebagai

\footnotetext{
${ }^{18}$ Jawaban tertulis dan hasil wawancara dengan Basir Rohrohmana, dosen Fakultas Hukum Universitas Cenderawasih Jayapura, Papua, pada tanggal 1 Oktober 2012.

${ }^{19}$ Jawaban tertulis dan hasil wawancara dengan Muhammad Ikhsan, dosen Fakultas Hukum Universitas Sriwijaya, Palembang, pada tanggal 31 Oktober 2012.

${ }^{20}$ Jawaban tertulis dan hasil wawancara dengan Basir Rohrohmana, Op. Cit.
} 
karya ratu Sinuhun penguasa Palembang dari 1639 sampai 1650 dan Kitab Simbur Cahaya mengandung materi hukum peraturan pergaulan umum masyarakat, pergaulan remaja, aturan pemerintahan adat, aturan berladang dan aturan penghukuman. Sanksi pidana adatnya antara lain adalah sedekah kambing pembasuh dusun berupa sedekah membuang sial dan lain-lain. Pada masa lampau, saat hukum adat masih eksis keberadaannya, kekuatan hukum putusan adat sangat kuat dan dihargai oleh masyarakat karena pengadilan adat seperti Rapat Marga dianggap sebagai personifikasi rasa keadilan masyarakat. Pada masa lampau tersebut peranan dari Kepala Marga (pasirah), penghulu sangat penting dalam pengambilan putusan adat.

Menurut Muhammad Ikhsan, ${ }^{21}$ di Sumatera Selatan pada saat ini tidak ada peraturan daerah yang secara khusus mengatur mengenai sanksi pidana adat dan proses peradilan pidana melalui Pengadilan Adat. Tindak pidana adat di Sumatera Selatan sudah berangsur-angsur menghilang yang masih ada hanya mengenai adat istiadat. Mengenai adat istiadat ini, di kabupaten Muara Enim terdapat Perda No. 2 Tahun 2007 tentang Lembaga Adat Marga. Pasal 10 Perda ini menentukan bahwa Pemangku Adat Marga mempunyai tugas melakukan pembinaan, pelestarian, penggalian, dan pengembangan adat istiadat dan budaya serta pemberdayaan masyarakat hukum adat. Selanjutnya dalam Pasal 12 huruf g terdapat ketentuan yang terkait dengan sanksi adat. Pasal 12 huruf g Perda ini menentukan bahwa Pemangku Adat Marga antara lain mempunyai wewenang memberikan sanksi adat kepada seseorang yang melanggar ketentuan hukum adat. Pasal 23 Perda ini juga menentukan bahwa pelanggaran terhadap ketentuan adat dapat dikenakan sanksi adat berdasarkan hasil rapat dan musyawarah Pemangku Adat Marga. Namun Perda ini tidak menentukan apa yang dimaksud dengan hukum adat dan sanksi adat apa yang dikenakan kepada orang yang melanggar hukum adat tersebut.

Selain Muara Enim, saat ini kabupaten Banyuasin di Sumatera Selatan memiliki Rancangan Perda tahun 2012 tentang Keberadaan Masyarakat Hukum Adat dan Kompilasi Adat Istiadat Kabupaten Banyuasin. Dalam Rancangan Perda ini terdapat beberapa ketentuan Pasal yang digolongkan sebagai hukum silang sengketa adat antara lain: tidak dibenarkan laki-laki memegang dan/atau memeluk badan gadis atau randa (meragang gawe) Pasal 70; tidak dibenarkan laki-laki menangkap/ merebut kain atau kemban/selendang gadis (nangkap rimau) (Pasal 71); tidak

\footnotetext{
${ }^{21}$ Jawaban tertulis dan hasil wawancara dengan Muhammad Ikhsan, Op. Cit.
} 
dibenarkan laki-laki memegang dan/atau memeluk istri orang (naro gawe) ( Pasal 72), anggota masyarakat tidak dibenarkan melakukan perbuatan sumbang, baik sumbang besar maupun sumbang kecil, dan sebagainya. Pelanggaran terhadap perbuatan yang digolongkan sebagai hukum silang sengketa adat akan mendapatkan reaksi adat dengan mengindahkan ketentuan peraturan perundangundangan yang berlaku.

Adanya ketentuan bahwa pemberlakuan reaksi adat adalah dengan tetap mengindahkan ketentuan peraturan perundang-undangan yang berlaku, maka pemberlakuan hukum adat tidak boleh bertentangan dengan hukum positif (hukum negara) atau hukum yang berlaku. Dengan demikian, apabila tindak pidana adat terdapat padanannya dalam peraturan perundang-undangan yang berlaku maka pelanggaran atas perbuatan atau tindak pidana tersebut akan dikenakan sanksi pidana berdasarkan peraturan perundang-undangan yang berlaku tersebut.

Pihak kepolisian dari Polda Sumatera Selatan menyatakan bahwa tindak pidana adat/hukum adat tidak tertulis secara konsepsional dan tidak tersosialisasi secara luas, sehingga sangat sulit untuk mengetahui tentang rumusan dari item-item pelanggaran tindak pidana adat dan apa saja sanksi adatnya. Hukum adat tersebut saat ini sudah hampir hilang oleh karena tindak pidana adat ini hanya diketahui oleh generasi terdahulu dan tidak diwariskan kepada generasi berikutnya inilah kesulitannya untuk mengetahui tindak pidana adat yang terdapat pidananya. ${ }^{22}$

Menurut Muhammad Ikhsan, ${ }^{23}$ tidak semua perbuatan pidana yang terdapat dalam KUHP dan undang-undang lainnya diatur dalam hukum pidana adat. Jika suatu tindak pidana adat terdapat padanannya dalam KUHP atau undang-undang lainnya maka seharusnya diterapkan sanksi pidana pokok menurut hukum pidana negara sedangkan sanksi pidana adat dapat diletakkan sebagai pidana tambahan yang mengakomodir rasa keadilan masyarakat yang terganggu keseimbangannya pada saat kaidah tersebut dilanggar.

Sedangkan menurut Basir, ${ }^{24}$ secara sistematis sukar dilakukan bandingan (padanan) antara tindak pidana yang diatur dalam KUHP dan tindak pidana dalam Hukum Adat. Hukum pidana adat menggunakan patokan bahwa setiap perbuatan yang bertentangan dengan perasaan keadilan masyarakat dan mengganggu

\footnotetext{
${ }^{22}$ Hasil wawancara dan jawaban tertulis dengan Sudaryanto, Komisaris Besar Polisi, Kabid Hukum Kepolisian Daerah Sumatera Selatan, tanggal 29 Oktober 2012.

${ }^{23}$ Jawaban tertulis dan hasil wawancara dengan Muhammad Ikhsan, Op. Cit.

${ }^{24}$ Jawaban tertulis dan hasil wawancara dengan Basir Rohromana, Op. Cit.
} 
keseimbangan kosmis adalah pelanggaran adat. Tetapi digunakan konsepsi rechtsdelict, maka sebagian besar perbuatan dalam KUHP yang dipandang sebagai tindak pidana terdapat pula dalam masyarakat hukum adat, sepanjang tidak berkaitan dengan kepentingan politik kenegaraan (pemerintah).

Salah satu kekhususan Otonomi Khusus (Otsus) bagi Provinsi Papua adalah adanya penyelenggaraan Pengadilan Adat. Provinsi Papua memiliki 2 (dua) instrumen hukum berkaitan dengan peradilan adat, yaitu sebagaimana diatur dalam Pasal 51 UU No. 21 Tahun 2001 tentang Otonomi Khusus bagi Provinsi Papua dan Peraturan Daerah Khusus (Perdasus) Papua No. 20 Tahun 2008 tentang Peradilan Adat di Papua.

Pasal 50 ayat (2) UU No. 21 Tahun 2001 tentang Otonomi Khusus bagi Propinsi Papua menentukan bahwa selain kekuasaan kehakiman (yang dilaksanakan oleh Badan Peradilan sesuai dengan peraturan perundang-undangan), diakui adanya peradilan adat di dalam masyarakat hukum adat tertentu. Selanjutnya Pasal 51 ayat (1) menentukan bahwa peradilan adat adalah peradilan perdamaian di lingkungan masyarakat hukum adat, yang mempunyai kewenangan memeriksa dan mengadili sengketa perdata adat dan perkara pidana di antara warga masyarakat hukum adat yang bersangkutan. ${ }^{25}$

Dalam hal salah satu pihak yang bersengketa atau yang berperkara berkeberatan atas putusan yang telah diambil oleh pengadilan adat, pihak yang berkeberatan tersebut berhak meminta kepada pengadilan tingkat pertama di lingkungan badan peradilan yang berwenang untuk memeriksa dan mengadili ulang sengketa atau perkara yang bersangkutan (Pasal 51 ayat (4) UU Otonomi Khusus). Putusan pengadilan adat mengenai tindak pidana yang perkaranya tidak dimintakan pemeriksaan ulang sebagaimana yang dimaksud pada ayat (4), menjadi putusan akhir dan berkekuatan hukum tetap (Pasal 51 ayat (6)).

Selanjutnya Pasal 51 ayat (7) menentukan bahwa untuk membebaskan pelaku pidana dari tuntutan pidana menurut ketentuan hukum pidana yang berlaku, diperlukan pernyataan persetujuan untuk dilaksanakan dari Ketua Pengadilan Negeri yang mewilayahinya yang diperoleh melalui Kepala Kejaksaan Negeri yang bersangkutan dengan tempat terjadinya peristiwa pidana. Apabila permintaan pernyataan persetujuan untuk dilaksanakan bagi putusan pengadilan adat

${ }^{25}$ Undang-Undang Nomor 21 Tahun 2001 tentang Otonomi Khusus bagi Propinsi Papua. 
sebagaimana dimaksud pada ayat (7) ditolak oleh Pengadilan Negeri, maka putusan pengadilan adat sebagaimana dimaksud pada ayat (6) menjadi bahan pertimbangan hukum Pengadilan Negeri dalam memutuskan perkara yang bersangkutan (Pasal 51 ayat (8)).

Keadaan yang terjadi pada masyarakat adat Papua bahwa perkara pidana yang diselesaikan melalui peradilan pidana (negara) tidak selamanya menghapus tuntutan pidana adat, sehingga kadangkala pelaku tindak pidana terkena dualisme sanksi antara pidana adat dan pidana yang dikenakan oleh peradilan negara. Oleh karena itu, menurut Basir, pemenuhan kewajiban adat merupakan solusi alternatif yang bijak. Pemenuhan kewajiban adat bagi penyelesaian perkara adat di Papua adalah konstruktif sekaligus sebagai salah satu solusi bijak dalam mengatasi dualisme pengenaan sanksi pidana yang dialami oleh pelaku tindak pidana (terpidana).

Menurut Basir, ${ }^{26}$ pemenuhan kewajiban adat berpeluang diterapkan di Papua, mengingat secara antropologis 250 suku lebih masyarakat asli Papua masih hidup terikat dalam lingkungan persekutuan masyarakat adat, dan sangat menjujung tinggi pemberlakuan hukum adat. Namun demikian, pemenuhan kewajiban adat sebagai pidana tambahan yang dikenakan peradilan negara terhadap pelaku tindak pidana sebagai pidana tambahan terkendala pada tataran eksekusi, karena (1) eksekutor negara seperti jaksa dipandang tidak berwenang memasuki ranah adat untuk menjalankan pemenuhan kewajiban adat, (2) Hakim yang menjatuhkan pidana pemenuhan kewajiban adat dikuatirkan tidak memahami bentuk/jenis pidana apa yang seharusnya dikenakan kepada pelaku tindak pidana, sehingga pemenuhan kewajiban adat diserahkan kembali kepada adat masing-masing suku yang serba beragam di Papua ini.

Di Papua, putusan adat dilaksanakan oleh eksekutor adat seperti Ondoafi melalui Abu Akho sebagai perpanjangan tangan Ondoafi yang ditugaskan Ondoafi sebagai kepala adat untuk melaksanakan putusan adat, dan tingkat kepatuhan terhukum terhadap pelaksanaan eksekusi putusan adat cukup tinggi. Sedangkan Hakim Adat di Papua biasanya adalah kepala suku seperti Nati, Ondoafi, Ontofro, Yoskondor, Manambri, Menagawan, tetapi bisa juga ditunjuk salah seorang kepala Keret/Kepala Klan atau kepada marga untuk menjadi hakim adat. Hakim Adat di

${ }^{26}$ Jawaban tertulis dan hasil wawancara dengan Basir Rohromana, Op. Cit. 
Papua hanya berwenang mengadili berdasarkan kompetensi internal suku atau adat bersangkutan, dan sebab itu agak sulit diterima orang dari luar suku untuk menjadi hakim adat untuk menyelesaikan perkara internal dari warga masyarakat hukum adat tertentu.

Menurut Muhammad Ikhsan, ${ }^{27}$ jika semangat hukum adat akan diakomodir dalam pembangunan hukum ke depan, maka hakim yang mengadili adalah hakim yang berlatarbelakang ilmu pengetahuan yang luas dan mendalam. Muhammad Ikhsan mengilustrasikan bahwa dengan kondisi saat ini di mana mestinya hakim pada waktu menempuh pendidikan S1 ilmu hukum telah belajar banyak hal tentang pengetahuan yang berhubungan dengan kondisi riil masyarakat seperti sosiologi hukum dan anthropologi. Oleh karena itu, seharusnya hakim bijak dalam memutus segala hal dengan berdasarkan ilmu pengetahuan yang dimilikinya.

Muhammad Ikhsan menyatakan bahwa, sanksi pidana tambahan dalam RUU KUHP harus memuat pidana pemenuhan kewajiban adat sebagai upaya mengembalikan keseimbangan kosmis yang terganggu karena perilaku melanggar aturan adat. Oleh karena itu, semangat pembaharuan hukum adat tersebut untuk mengembalikan kearifan lokal dalam menata masyarakat maka sanksi pidana tambahan yang berupa pemenuhan kewajiban adat tetap memiliki peluang besar diterima dengan terbuka oleh masyarakat. Menurut Muhammad Ikhsan, segala sesuatu tentu memiliki kendala ketika pertama kali diterapkan kembali setelah sekian lama tenggelam di dasar samudra, kendala tersebut relatif lebih mudah akan teratasi.

Demikian pula dari pihak kepolisian Polda Sumatera Selatan sependapat bahwa pemenuhan kewajiban adat dapat menjadi sanksi pidana tambahan dalam RUU KUHP karena masih ada perbuatan yang melanggar norma baik norma hukum maupun norma adat yang tidak terjangkau KUHP. Namun perbuatan yang dianggap melanggar norma tersebut tetap perlu dimasukan ke dalam peraturan perundangundangan (RUU KUHP). Pada kenyataannya masih terdapat masyarakat yang menjunjung norma-norma adat dari tiap-tiap sukunya dan mereka percaya bahwa hukum adat bersifat magis yang memiliki kekuatan supra natural pada benda-benda tertentu. Namun, sanksi pidana hukum negara diprioritaskan penerapannya dalam setiap pelanggaran norma hukum.

Mengenai pemenuhan kewajiban adat sebagai pidana tambahan, menurut pihak kepolisian dari Polda Sumatera Selatan, dalam pelaksanaannya dimungkinkan

${ }^{27}$ Jawaban tertulis dan hasil wawancara dengan Muhammad Ikhsan, Op. Cit. 
menghadapi kendala karena hukum adat bersifat lokal dan berbeda-beda yang dapat berlaku hanya di kalangan masyarakat kelompok tertentu. Selain itu, hukum adat tidak tertulis secara konsepsional, sehingga akan sulit dipahami oleh masyarakat kelompok lain. Hukum adat juga mengalami perubahan mengikuti perkembangan masyarakat.

Namun, menurut Mardjono Reksodiputro, menjadikan hukum adat yang hidup sebagai salah satu sumber hukum pidana Indonesia memiliki alasan pembenaran antara lain adanya tugas seorang hakim yang berkewajiban mencari keadilan. Untuk upaya ini maka hakim harus menjaga bahwa seseorang yang bersalah melakukan perbuatan yang dicela oleh masyarakat dan patut dipidana memang mendapatkan pidananya. Ukuran perbuatan apa yang "tercela" dan "patut dipidana" dapat ditentukan oleh pembentuk undang-undang, tetapi dapat pula didasarkan pada hukum adat yang hidup dalam masyarakat yang bersangkutan. Kewajiban hakim mencari keadilan itu dapat dilihat pula dalam ketentuan UU tentang Kekuasaan Kehakiman yang melarang hakim menolak untuk memeriksa dan mengadili suatu perkara yang diajukan seorang "korban", serta kewajibannya untuk menggali nilainilai hukum yang hidup. ${ }^{28}$

Dalam kaitan asas legalitas dan asas sifat melawan hukum, dengan adanya perluasan asas legalitas, yaitu dengan mengakui adanya tindak pidana adat, maka akan terkait pula dengan pembahasan mengenai asas sifat melawan hukum materiil. Tujuan dari asas legalitas adalah untuk menguatkan asas kepastian hukum yaitu dengan hanya memperhatikan ketentuan tertulis. Namun demikian, asas keadilan juga harus menjadi perhatian, yaitu dengan adanya nilai-nilai yang hidup dalam masyarakat. Oleh karena itu, meskipun unsur-unsur aturan tertulis telah dipenuhi oleh perbuatan yang bersangkutan, asas sifat melawan hukum materiil dapat merupakan alasan penghapus pidana. Dalam hal tindak pidana adat, maka apa yang terjadi adalah bahwa hakim tidak mempergunakan asas legalitas dan menerima adanya sifat melawan hukum (celaan kuat oleh masyarakat hukum adat) untuk memidana seorang pelaku. Jadi dengan demikian, asas sifat melawan hukum materiil tidak dipergunakan sebagai alasan penghapus pidana. ${ }^{29}$

Mengenai perluasan asas legalitas masih menimbulkan pertanyaan bagi pakar hukum pidana lainnya. Harkristuti Harkrisnowo mengingatkan, agar penyusun RUU

${ }^{28}$ Mardjono Reksodiputro, Menyelaraskan Pembaruan Hukum, Jakarta, Komisi Hukum Nasional RI, 2009, hlm. 87. ${ }^{29}$ Ibid. 
KUHP memperhatikan implikasi masuknya delik adat ke dalam RUU KUHP, karena ada sejumlah pertanyaan yang harus dijawab agar perumusan RUU tersebut jelas. Menurut Harkristuti, harus jelas hukum adat mana saja yang masih berlaku, dan bagian mana dari hukum adat itu yang masih berlaku. Selanjutnya, apa arti “yang masih berlaku"? Menurut Harkristuti, masih ada hukum adat yang permisif atas kekerasan terhadap perempuan dan anak-anak. Oleh karena itu, hukum adat yang dimaksud harus berstandar hak asasi manusia. Penerimaan hukum adat juga menyulitkan ketika diterapkan di pengadilan karena hakim belum tentu paham hukum adat setempat dimana dia bertugas. Akibatnya, hukum menjadi tidak pasti dan berpotensi diskriminatif. ${ }^{30}$

Konsekuensi logis diakui dan adanya dasar hukum yang tegas eksistensi hukum yang hidup (hukum pidana adat) akan memberikan tugas, tanggung jawab dan beban relatif lebih berat kepada hakim untuk lebih dapat memahami dan menggali nilai-nilai hukum yang hidup dalam masyarakat. Hakim harus benarbenar memahami perasaan masyarakat, keadaan masyarakat, terlebih masyarakat Indonesia yang majemuk dengan pelbagai macam adat istiadat, tradisi dan budaya yang berbeda-beda.

\section{Pidana "Pemenuhan Kewajiban Adat Setempat Atau Kewajiban Menurut Hukum yang Hidup dalam Masyarakat" dan Prinsip Restorative Justice System.}

Dalam setiap lima tahun sekali PBB menyelenggarakan kongres yang dikenal dengan nama "Congress on Crime Prevention and The Treatment of Offenders". Kongres ini bertujuan untuk membicarakan dan mendiskusikan tentang perkembangan kejahatan, penanggulangannya dan penanganan pelaku kejahatan serta berbagai topik terkait. Pada kongres yang diselenggarakan di 1990 dan 1995, beberapa lembaga swadaya masyarakat dari beberapa negara mensponsori sejumlah sesi pertemuan untuk secara khusus berdiskusi tentang restorative justice. Pada 1995, dalam sejumlah sesi pertemuan di kongres yang dilaksanakan di Kairo, dibicarakan secara tajam dan mendalam hal-hal teknis yang berkaitan dengan penggunaan pendekatan restorative justice dalam penanganan perkara pidana. Hingga pada kongres selanjutnya yang digelar pada 2000 dihasilkan United Nation, Basic Principles

\footnotetext{
${ }^{30}$ Delik Adat dalam RUU KUHP Dikritik. Hukum adat bisa diterima jika berstandar hak asasi manusia. Kamis, 23 Desember 2010. http://hukumonline.com/berita/baca/lt4d12cf6ce41a4/delik-adat-dalam-ruu-kuhp-dikritik1, diakses 23 Desember 2012.
} 
on The Use of Restoratif Justice Programmes in Criminal Matters yang berisi sejumlah prinsip-prinsip mendasar dari penggunaan pendekatan restorative justice. ${ }^{31}$

Pendekatan restorative justice diasumsikan sebagai pergeseran paling mutakhir dari berbagai model dan mekanisme yang bekerja dalam sistem peradilan pidana dalam menangani perkara-perkara pidana pada saat ini. Di banyak negara di dunia, ketidakpuasan dan rasa frustasi terhadap hukum pidana formal telah memicu sejumlah pemikiran untuk melakukan upaya alternatif dalam menjawab persoalanpersoalan yang berkaitan dengan penanganan tindak pidana yang terjadi di negara tersebut. Permasalahan seputar perkembangan sistem peradilan pidana yang ada sekarang menunjukkan bahwa sistem ini dianggap tidak lagi dapat memberikan perlindungan terhadap hak asasi manusia serta transparansi terhadap kepentingan umum yang dijaga pun semakin tidak dirasakan. ${ }^{32}$

PBB melalui Basic principles yang telah digariskannya menilai bahwa pendekatan restorative justice adalah pendekatan yang dapat dipakai dalam sistem peradilan pidana yang rasional. Hal ini sejalan dengan pandangan G. P. Hoefnagels yang menyatakan bahwa politik kriminil harus rasional (a rational total of the responses to crime). Pendekatan restorative justice merupakan suatu paradigma yang dapat dipakai sebagai bingkai dari strategi penanganan perkara pidana yang bertujuan menjawab ketidakpuasan atas bekerjanya sistem peradilan pidana yang ada saat ini. ${ }^{33}$

Restorative justice juga menjadi model pendekatan baru dalam RUU KUHP. Beberapa konsep restorative justice yang telah diakomodir dalam RUU KUHP antara lain: keseimbangan antara nilai-nilai yang hidup dalam masyarakat dan asas legalitas, salah satu tujuan pemidanaan adalah menyelesaikan konflik sosial dan membebaskan rasa bersalah terpidana, dalam menjatuhkan pidana perlu dipertimbangkan pengaruh tindak pidana terhadap korban atau keluarga korban, adanya pemaafan dari korban atau keluarganya, pandangan masyarakat terhadap tindak pidana yang dilakukan, adanya jenis pidana pengawasan dan pidana kerja sosial, adanya jenis pidana tambahan berupa pembayaran ganti kerugian dan pemenuhan kewajiban adat setempat atau kewajiban menurut hukum yang hidup dalam masyarakat, dan adanya ketentuan bahwa pidana penjara sejauh mungkin

${ }^{31}$ Eva Achjani Zulfa, Restorative Justice di Indonesia (Peluang dan Tantangan Penerapannya), makalah yang disampaikan dalam Focus Group Discussion di Pusat Pengkajian, Pengolahan Data dan Informasi (P3DI) Sekretariat Jenderal DPR RI pada tanggal 26 September 2012.

${ }^{32}$ Ibid.

${ }^{33}$ Ibid. 
tidak dijatuhkan antara lain jika kerugian dan penderitaan korban tidak terlalu besar, dan sebagainya.

Berbeda dengan pendekatan yang dipakai pada sistem peradilan pidana konvensional, pendekatan ini menitikberatkan pada adanya partisipasi langsung pelaku, korban dan masyarakat dalam proses penyelesaian perkara pidana. Restorative justice adalah sebuah konsep pemikiran yang merespon pengembangan sistem peradilan pidana dengan menitikberatkan pada kebutuhan pelibatan masyarakat dan korban yang dirasa tersisihkan dengan mekanisme yang bekerja pada sistem peradilan pidana yang ada pada saat ini. Di pihak lain, restorative justice juga merupakan suatu kerangka berfikir yang baru yang dapat digunakan dalam merespon suatu tindak pidana bagi penegak dan pekerja hukum. Penanganan perkara pidana dengan pendekatan restorative justice menawarkan pandangan dan pendekatan berbeda dalam memahami dan menangani suatu tindak pidana. Dalam pandangan restorative justice makna tindak pidana pada dasarnya sama seperti pandangan hukum pidana pada umumnya yaitu serangan terhadap individu dan masyarakat serta hubungan kemasyarakatan. Akan tetapi dalam pendekatan restorative justice, korban utama atas terjadinya suatu tindak pidana bukanlah negara, sebagaimana dalam sistem peradilan pidana yang sekarang ada. Oleh karenanya kejahatan menciptakan kewajiban untuk membenahi rusaknya hubungan akibat terjadinya suatu tindak pidana. Sementara keadilan dimaknai sebagai proses pencarian pemecahan masalah yang terjadi atas suatu perkara pidana dimana keterlibatan korban, masyarakat dan pelaku menjadi penting dalam usaha perbaikan, rekonsiliasi, dan penjaminan keberlangsungan usaha perbaikan tersebut. ${ }^{34}$

Dalam sistem peradilan pidana, perlindungan terhadap korban kejahatan mempunyai argumentasi sebagai berikut. ${ }^{35}$ Pertama, proses pemidanaan mengandung pengertian, baik dalam arti umum maupun dalam arti konkrit. Dalam arti umum, proses pemidanaan merupakan wewenang pembentuk undang-undang, sesuai dengan asas legalitas, yang menegaskan bahwa, baik "poena" maupun "crimen" harus ditetapkan terlebih dahulu apabila hendak menjatuhkan pidana terhadap pelaku. Dalam arti konkrit, proses pemidanaan berkaitan dengan penetapan pidana melalui infrastruktur penintensier (hakim, petugas lembaga pemasyarakatan dan sebagainya). Di sini, terkandung tuntutan moral, dalam wujud keterkaitan filosofis pada satu pihak dan keterkaitan sosiologis dalam kerangka hubungan antar manusia dalam masyarakat pada lain pihak.

\footnotetext{
${ }^{34}$ Ibid.

${ }^{35}$ Muladi, Hak. Asasi Manusia, Politik, dan Sistem Peradilan Pidana, Universitas Diponegoro, Semarang, 2002, hlm. 176.
} 
Secara sosiologis, semua warga negara harus berpartisipasi penuh dalam kehidupan kemasyarakatan, masyarakat dianggap sebagai suatu wujud sistem kepercayaan yang melembaga. Tanpa kepercayaan ini, kehidupan sosial tidak mungkin berjalan dengan baik, sebab tidak ada pedoman atau patokan yang pasti dalam bertingkah laku. Kepercayaan ini terpadu melalui norma-norma yang diekspresikan di dalam struktur kelembagaan seperti kepolisian, kejaksaan, pengadilan, dan sebagainya. Terjadinya kejahatan atas diri korban, akan bermakna penghancuran sistem kepercayaan tersebut, pengaturan hukum pidana dan hukum lain yang menyangkut masalah korban dan berfungsi sebagai sarana pengembalian sistem kepercayaan tersebut.

Kedua, argumentasi lain yang mengedepankan perlindungan hukum bagi korban kejahatan adalah argumen kontrak sosial dan argumen solidaritas sosial. Argumen kontrak sosial menyatakan bahwa negara boleh dikatakan memonopoli seluruh reaksi sosial terhadap kejahatan dan melarang tindakan-tindakan yang bersifat pribadi. Oleh karena itu, jika terjadi kejahatan dan membawa korban, negara harus bertanggung jawab untuk memperhatikan kebutuhan korban tersebut. Argumen solidaritas sosial menyatakan bahwa negara menjaga warga negaranya dalam memenuhi kebutuhannya atau apabila warga negaranya mengalami kesulitan, melalui kerjasama dalam masyarakat berdasarkan atau menggunakan sarana-sarana yang disediakan oleh negara. Hal ini bisa dilakukan baik melalui peningkatan pelayanan maupun melalui pengaturan hak.

Ketiga, perlindungan korban kejahatan biasanya dikaitkan dengan salah satu tujuan pemidanaan, yang dewasa ini banyak dikedepankan yakni penyelesaian konflik. Penyelesaian konflik yang ditimbulkan oleh tindak pidana, memulihkan keseimbangan, dan mendatangkan rasa damai dalam masyarakat. Hal ini juga diadopsi dalam Pasal 54 ayat (1) huruf c RUU KUHP.

RUU KUHP telah memuat beberapa ketentuan yang memiliki konsep restorative justice. Konsep restorative justice tersebut tercantum antara lain: 1) dalam pembentukan norma hukum pidana, Pasal 2 ayat (1) pada intinya menegaskan bahwa asas legalitas tidak mengurangi berlakunya hukum yang hidup dalam masyarakat yang menentukan bahwa seseorang patut dipidana walaupun perbuatan tersebut tidak diatur dalam peraturan perundang undangan. Namun berlakunya hukum yang hidup dalam masyarakat tersebut sepanjang sesuai dengan nilai-nilai yang terkandung dalam Pancasila, hak asasi manusia, dan prinsip-prinsip hukum umum yang diakui 
oleh masyarakat bangsa-bangsa; 2) dalam perumusan tujuan pemidanaan, Pasal 54 ayat (1) huruf c menentukan bahwa tujuan pemidanaan adalah menyelesaikan konflik yang ditimbulkan oleh tindak pidana, memulihkan keseimbangan, dan mendatangkan rasa damai dalam masyarakat; 3) dalam perumusan jenis pidana yang terdapat dalam Pasal 65 sampai Pasal 100. Jenis pidana pokok antara lain: pidana pengawasan dan pidana kerja sosial. Jenis pidana tambahan antara lain: pembayaran ganti kerugian dan pemenuhan kewajiban adat setempat atau kewajiban menurut hukum yang hidup dalam masyarakat. Pidana tambahan dapat dijatuhkan bersama-sama dengan pidana pokok, sebagai pidana yang berdiri sendiri atau dapat dijatuhkan bersama-sama dengan pidana tambahan yang lain. Mengenai pidana tambahan berupa pemenuhan kewajiban adat setempat atau kewajiban menurut hukum yang hidup dalam masyarakat dapat dijatuhkan walaupun tidak tercantum dalam perumusan tindak pidana.

Baik Basir maupun Muhammad Ikhsan menyatakan, bahwa pemenuhan kewajiban adat akan memenuhi prinsip restorative justice sepanjang ada keterlibatan korban secara langsung mengajukan tuntutan kepada pelaku, dan sepanjang ada mekanisme yang diciptakan bagi pengakuan kesalahan dari pelaku dan kesediaan pelaku untuk menebus kesalahannya itu terhadap korban. Dari sisi kemasyarakatannya, restorative justice sebetulnya harus diberi ruang sebagai forum tanggung jawab bersama untuk menyelesaikan perkara pidana secara adil dan memperhatikan kepentingan semua pihak baik pelaku, korban, maupun masyarakat.

Meskipun Ketentuan Umum Hukum Pidana yang dimuat dalam Buku I RUU KUHP telah memuat beberapa ketentuan yang memiliki corak keadilan restoratif, namun perumusan norma hukum pidana dan perumusan ancaman sanksi pidana sebagaimana dimuat dalam Buku II RUU KUHP tidak tampak aspek filsafat keadilan restorative, justru lebih menampakkan corak keadilan retributive daripada keadilan restorative. Jika tujuan pemidanaan disepakati sebagai perwujudan dari filsafat (umum) hukum pidana dan pemidanaan dalam sistem hukum pidana nasional sebagaimana berlaku di negara-negara lain, seharusnya corak filsafat restorative justice lebih tampak menonjol dalam merumuskan ketentuan umum hukum pidana dan perumusan norma hukum pidana serta ancaman sanksi pidana dalam RUU KUHP Buku II. ${ }^{36}$

${ }^{36}$ Mudzakkir, Pembaruan Hukum Pidana Nasional dan Implikasinya dalam Kebidupan Masyarakat (Konsep Restorative Justice, Diversi, Rekonsiliasi, Mediasi, dan Alternative Dispute Resolution), makalah disampaikan pada kegiatan Round Table Discussion RUU KUHP dengan topik "Pembaruan Hukum Pidana Nasional dan Implikasinya dalam Kehidupan Masyarakat (Konsep Restorative Justice, Diversi, Rekonsiliasi, Mediasi, dan Alternative Dispute Resolution), diselenggarakan oleh Kementerian Hukum dan HAM RI, Direktorat Jenderal Perundang-undangan, Hotel Grand Melia, Jakarta, 24-25 Agustus 2010, hlm. 11. 
Konsep restorative justice juga telah diakomodir dalam RUU tentang Kitab UndangUndang Hukum Acara Pidana (RUU KUHAP), antara lain terkait dengan penyelesaian perkara di luar pengadilan (out of court settlement) untuk perkara-perkara tertentu, kewenangan penuntut umum untuk menghentikan penuntutan dalam perkara-perkara tertentu, dan sebagainya. RUU KUHAP juga berorientasi pada perlindungan hak asasi manusia, menghapuskan praktek-praktek kuno dan formalistik, reformasi birokrasi sistem peradilan pidana, modernisasi aturan pembuktian, dan keberpihakan pada korban dan kelompok rentan. ${ }^{37}$ Namun demikian, RUU KUHAP belum mengatur tentang bagaimana mekanisme penyelesaian konflik yang ditimbulkan oleh tindak pidana, memulihkan keseimbangan dan mendatangkan rasa damai dalam masyarakat dan siapa dilibatkan dalam penyelesaian konflik yang ditimbulkan oleh tindak pidana tersebut serta bentuk instrumen penyelesaian konflik yang ditimbulkan oleh tindak pidana lainnya. ${ }^{38}$

Jika pembaruan hukum pidana memiliki komitmen untuk menempatkan restorative justice sebagai landasan filsafat pembaruan hukum pidana nasional, maka perlu dilakukan kajian secara cermat, mendalam dan komprehensif untuk memasukkan instrument restorative justice ke dalam pembaruan hukum pidana materiil dan hukum pidana formil yang dipandang tepat dengan sistem hukum pidana nasional. ${ }^{39}$

Dalam praktek selama ini, konsep restorative justice telah lama diterapkan oleh POLRI khususnya terhadap kasus-kasus tindak pidana aduan, penganiayaan ringan, kecelakaan ringan pada lalu lintas, dan sebagainya. Dalam hal ini aparat penegak hukum melakukan "upaya damai" dalam arti positif. Oleh karena itu pendekatan restorative justice disarankan juga dapat dilakukan pada tahap penyidikan demi efisiensi, hanya saja mekanismenya memang perlu diatur secara jelas. ${ }^{40}$

Menurut pihak kepolisian dari Polda Sumatera Selatan, ${ }^{41}$ bahwa dalam menegakkan hukum Polri merupakan bagian (sub sistem) dalam sistem peradilan pidana, sebagai penyidik, yang melakukan penyidikan terhadap pelanggaran tindak

${ }^{37}$ Laporan Hasil Round Table Discussions Rancangan Undang-Undang tentang Hukum Pidana (RUU KUHP), Strategi Pembahasan RUU KUHP di DPR RI dan Pembaruan Hukum Pidana Nasional dan Implikasinya Dalam Kehidupan Masyarakat, Kerjasama Kementerian Hukum dan HAM RI dengan OPDAT U.S. Embassy, Hotel Grand Melia Jakarta, 25 Agustus 2010, hlm. 2.

${ }^{38}$ Mudzakkir, Pembaruan Hukum Pidana..., Op. Cit., hlm. 12.

${ }^{39}$ Ibid.

${ }^{40}$ Laporan Hasil Round Table Discussions Rancangan Undang-Undang tentang Hukum Pidana (RUU KUHP), Strategi Pembahasan RUU KUHP, hlm. 2.

${ }^{41}$ Hasil wawancara dan jawaban tertulis dengan Sudaryanto, Komisaris Besar Polisi, Kabid Hukum Kepolisian Daerah Sumatera Selatan, tanggal 29 Oktober 2012. 
pidana pidana bukan tindak pidana adat. Selama ini, jika terjadi pelanggaran tindak pidana adat yang tidak termasuk tindak pidana pidana, Polri sebagai alat negara yang menjaga Kamtibmas melakukan penyelesaian melalui penerapan Polmas (Perkap No. 7 Tahun 2008) yaitu menekankan pada upaya pemecahan masalah yang terkait dengan tindak pidana adat dan ketidaktertiban secara proaktif bersama-sama dengan masyarakat (lembaga adat setempat atau Forum Kemitraan Polri dan Masyarakat (FKPM)).

\section{Penutup}

Pemenuhan kewajiban adat berpeluang diterapkan di Papua, mengingat secara antropologis 250 suku lebih masyarakat asli Papua masih hidup terikat dalam lingkungan persekutuan masyarakat adat, dan sangat menjunjung tinggi pemberlakuan hukum adat. Di Sumatera Selatan, meskipun terdapat juga peluang tersebut namun tindak pidana adat itu sendiri sudah berangsur-angsur hilang.

Meskipun pemenuhan kewajiban adat sebagai pidana tambahan berpeluang untuk diterapkan di Papua, namun jika melalui proses sistem peradilan negara akan menghadapi kendala pada tataran eksekusi, karena (1) eksekutor negara seperti jaksa dipandang tidak berwenang memasuki ranah adat untuk menjalankan pemenuhan kewajiban adat, (2) Hakim yang menjatuhkan pidana pemenuhan kewajiban adat dikuatirkan tidak memahami bentuk/jenis pidana apa yang seharusnya dikenakan kepada pelaku tindak pidana, sehingga dimungkinkan pemenuhan kewajiban adat diserahkan kembali kepada adat masing-masing suku yang beragam di Papua.

Pemenuhan kewajiban adat setempat atau kewajiban menurut hukum yang hidup dalam masyarakat sebagai pidana tambahan memenuhi prinsip restorative justice. Sebagaimana restorative justice maka pemenuhan kewajiban adat akan melibatkan pelaku, korban, dan masyarakat dalam upaya mengembalikan keseimbangan yang yang terganggu akibat dilanggarnya suatu kepentingan hukum di masyarakat.

Meskipun RUU KUHP mencantumkan adanya pidana pemenuhan kewajiban adat setempatataukewajiban menurut hukum yang hidup dalam masyarakatsebagai pidana tambahan namun RUU KUHP telah memberi batasan bahwa berlakunya hukum yang hidup dalam masyarakat tersebut sepanjang sesuai dengan nilai-nilai 
yang terkandung dalam Pancasila, hak asasi manusia, dan prinsip-prinsip hukum umum yang diakui oleh masyarakat bangsa-bangsa. Oleh karena itu menggali hukum yang hidup tidak berarti mengangkat begitu saja hukum pidana adat sebagai sumber hukum.Hal yang perlu dilakukan adalah menggali berbagai kesamaan asasasas dan norma-norma hukum pidana yang terkandung di dalam hukum yang hidup. Selanjutnya apabila asas dan norma tersebut sesuai dengan nilai-nilai Pancasila, tidak bertentangan dengan hak asasi manusia, dan prinsip-prinsip hukum dapat kiranya diangkat menjadi asas-asas dan norma-norma hukum pidana positif nasional.

Untuk memberi kepastian hukum maka hukum pidana adat dapat dirumuskan dalam bentuk tertulis. Naskah-naskah kuno seperti kakawin, pepakem, jayapatra, prasasti, lontara, kitab simbur cahaya dan awig-awig (hukum adat Bali yang sampai saat ini masih dipergunakan) merupakan contoh beberapa hukum adat yang tertulis.

Selanjutnya harus ada sinkronisasi dan harmonisasi antara RUU KUHP dan RUU KUHAP yang juga sudah mengadopsi konsep restorative justice sebagai salah satu upaya untuk meminimalisasi kendala yang mungkin timbul dalam penerapan konsep tersebut.

\section{Daftar Pustaka}

A.Garner, Bryan (Ed).,Black's law Dictionary, Eight edition, St.Paul, West Thomson, MN, 2004.

Allen, Michael J., Criminal Law,Edisi kelima, Blackstone Press Limited, London, 1999. Ashshofa, Burhan., Metode Penelitian Hukum, Rineka Cipta, Jakarta, 1998.

Arief, Barda Nawawi, Kapita Selekta Hukum Pidana, Citra Aditya Bakti, Bandung, 2010. Beberapa Aspek Kebijakan Penegakan Dan Pengembangan Hukum Pidana, Citra Aditya Bakti, Bndung, 1998.

Babbie, Early, The Practice of Sosial Research, CA. Wadsworth Publishing Company, Eight edition, Belmont, 1998.

Braithwaithe, John, Crime, Shame, and Reintegration, Cambridge University Press, UK, 1989.

, Restorative Justice E Responsive Regulation, Oxford University Press, New York, 2002.

Christiansen, Karl O., Some Consideration on the Possibility of a Rational Criminal Policy, Resource Maeriel Series, No. 7, UNAFEI, Tokyo, 1974. 
Clarkson, C.M.V., Understanding Criminal Law, Suveat \& Maxwell, London, 1998.

D. Miethe,Terance, Punishment A Comparative Historical Perspective, Cambridge University Press, UK, 2005.

Duff, R.A. and David Garland, A Reader on Punishment, Oxford University Press, New York, 1994.

Gross, Hyman., A Theory of Criminal Justice, Oxford University Press, New York, 1979.

Hoefnagels, G. Peter., The Other Side of Criminology, B. V. Deventer, Kluwer, 1969.

Makarao, Mohammad Taufik, Pembaharuan Hukum Pidana Indonesia-Studi Tentang Bentuk-bentuk Pidana Khususnya Pidana Cambuk Sebagai Suatu Bentuk Pemidanaan, Kreasi Wacana, Yogyakarta, 2005.

Marzuki, Peter Mahmud., Penelitian Hukum, Kencana Prenada Media Group, Cetakan ke-5, Jakarta, 2009.

Miethe, Terance D dan Hong Lu., Punishment A Comparative Historical Perspective, Cambridge University Press, 2005.

Moeljatno, Asas-Asas Hukum Pidana, Rineka Cipta, Jakarta, 2008.

Muladi dan Barda Nawawi Arief, Teori-Teori dan Kebijakan Pidana, Alumni, Bandung, 1998.

Muladi, Lembaga Pidana Bersyarat, Alumni, Bandung, 2008.

McMorville, Mike and Wing Hong Chui, Research Methods for Law, Edinburgh University Press, Edinburgh , 1988.

Nurjaya, I Nyoman, Pengelolaan Sumber Daya Alam dalam Perspektif Antropologi Hukum, Prestasi Pustaka Publisher, Jakarta, 2008.

Packer, Herbert L., The Limits Of The Criminal Sanstion, Stanford University Press, California, 1968.

Reksodiputro, Mardjono, Menyelaraskan Pembaruan Hukum, Komisi Hukum Nasional (KHN), Jakarta, 2009.

Reid, Sue Titus., Criminal Law, Edisi ketiga, Englewood, Prentice Hall, New Jersey, 1995.

Setiady, Tolib., Intisari Hukum Adat Indonesia (Dalam Kajian Kepustakaan), Alfabeta, Bandung, 2008.

Soekanto, Soerjono., Mengenal Antropologi Hukum, Penerbit Alumni, Bandung, 1982.

Soekanto, Soerjono dan Sri Mamudji, Penelitian Hukum Normatif Suatu Tinjauan Singkat, RajaGrafindo Persada, Jakarta, 2003.

Sunggono, Bambang,Metodologi Penelitian Hukum (Suatu Pengantar), RajaGrafindo Persada, Jakarta, 1997.

Tamanaha, Brian Z., Realistic Socio-legal Theory Pragmatism and a Social Theory of Law, Clarendon Press, Oxford, 1999. 
Warman, Kurnia., Hukum Agraria dalam Masyarakat Majemuk. Dinamika interaksi Hukum Adat dan Hukum Negara di Sumatera Barat, Huma, Jakarta, 2010.

Wignjosoebroto, Soetandyo, Hukum: Paradigma, Metode dan Dinamika Masalahnya, Elsam \& HuMa, Jakarta, 2002.

Zulfa, Eva Achjani, Pergeseran Paradigma Pemidanaan, Lubuk Agung, Bandung, 2001.

Harkrisnowo, Harkristuti, Pengaturan Mengenai Sanksi Pidana Dalam R-KUHP Dalam Perspektif HAM, Seri Diskusi Rancangan KUHP \#2, Catatan Seminar "Pembaharuan KUHP : Meninjau Kembali Bentuk-Bentuk Hukuman Dalam RUU KUHP", Komisi Nasional Hak Asasi Manusia (KOMNAS HAM), Lembaga Studi dan Advokasi Masyarakat (ELSAM), PAHAM Universitas Padjajaran, KAHAM Universitas Diponegoro, PUSHAM Universitas Surabaya, Bandung, 7 Desember 2005.

Rancangan Paper Academic Peraturan Daerah Khusus (Perdasus), Dibuat sebagai salah satu pentahapan penyusunan Draft Perdasus tentang Penyelenggaraan Peradilan Adat Di Propinsi Papua Menurut Undang-Undang Nomor 21 Tahun 2001 tentang Otonomi Khusus Bagi Propinsi Papua, Kerjasama Kepolisian Daerah Papua-Fakultas Hukum Universitas Cendrawasih dengan Partnership for Governance Reform In Indonesia, Jayapura, 2005.

Hukum Adat Mendominasi Hukum Positifdi Papua, http://budayapapua. wordpress.com/2009/07/08/hukum-adat-mendominasi-hukum-positif-dipapua/.

Barda Nawawi Arief, Mediasi Penal: Penyelesaian Perkara Pidana Di Luar Pengadilan, http:/ / bardanawawi.wordpress.com/2009/12/27/mediasi penal penyelesaian perkara pidana di luar pengadilan/.

Rancangan Undang-Undang tentang Kitab Undang-Undang Hukum Pidana (RUU KUHP), Kementerian Hukum dan Hak Asasi Manusia, Draf Tahun 2012. 